\title{
Effective Integration of Information and Communications Technology in Teacher Education
}

\author{
COLETTE MURPHY \& LILLIAN GREENWOOD \\ Queen's University, Belfast, United Kingdom
}

\begin{abstract}
Effective delivery of the new information technology (IT) curriculum for student teachers in the United Kingdom, which started in September 1998, is an important challenge for initial teacher training institutions. This article identifies three main obstacles that may limit its successful implementation - student access to computers, the communications and information technology (ICT) policy adopted by initial teacher training providers and the lack of encouragement for students to use ICT on teaching practice. The work is based on a survey carried out in 1997 of lecturers and students in three teacher training institutions in Northern Ireland. The findings have led to the proposal of basic guidelines to contribute towards the development and implementation of an effective ICT policy in initial teacher training institutions.
\end{abstract}

\section{Introduction}

It has been established that students in initial teacher education in the United Kingdom (UK) do not make sufficient use of communications and information technology (ICT). This article addresses that issue by determining the extent to which students use ICT both at college and in their placement schools. Students on two types of teacher training programme are compared: a Bachelor of Education (BEd) degree programme (four years), designed for students who will become primary teachers (for ages 5-11 years), and a one-year Postgraduate Certificate in Education (PGCE) for teachers at secondary level (for ages 11-18 years).

The study is based on work carried out in three teacher education institutions in Northern Ireland and considers the implications of effectively integrating ICT into initial teacher education. In analysing the application of $\mathrm{ICT}$, the article discusses how it is used by both students and lecturers. A second and important question concerning the application of ICT addresses 
the way in which computer access is made available to both lecturers and students. This in itself is an extremely important question because ICT uptake is dependent upon access to the required technology. The question of access is a particularly well-researched issue in universities in the UK. This article looks further at training in ICT and assesses the confidence of students to use ICT in their teacher training. It identifies three main problem areas which hinder the effective integration of ICT into teacher training courses and outlines a strategy which will enhance student ICT uptake.

\section{Literature Review}

The importance and advantages of using ICT in teaching have been widely reported. A recent discussion paper prepared by NCET (National Council for Educational Technology, 1997) argues that "Information technology is rapidly changing the world we live in. ICT is changing the nature of society and employment and is therefore changing the requirements placed on schools and colleges." Indeed, one of the recommendations of the Report of the National Committee of Inquiry into Higher Education (Dearing, 1997) was that "All higher education institutions in the UK should have in place overarching communications and information strategies by 1999/2000".

One of the principal advantages of the use of ICT in teaching and learning is that it enables schools and colleges to cater for the needs of the individual rather than to the average needs of the class. Another major advantage is that ICT can dramatically improve access to information for, and communication of ideas by, students with special learning needs.

ICT can be used across the curriculum to enhance student learning. For example, students can improve the quality of their written work in any subject by using word processing, which allows them to reflect on what they have written and make changes easily. Difficult concepts can be made simpler to understand when illustrated with animated graphics and computer simulations. Students can access high-quality information more easily using CD-ROMs and, to some extent, the Internet.

Projects investigating the use of ICT in learning have consistently highlighted the increased motivation of the learner (for a review, see Cox, 1997). Some explanations of this increased motivation (adapted from NCET, 1997) are that ICT has the flexibility to meet individual student needs; it can be used to present information in new ways which help students understand more readily; it can give students the power to try out different ideas and to take risks; and it can make learners more confident and able to challenge themselves more.

Within educational institutions, ICT can help save time and money, which can ultimately improve the use of the teacher's time. Reduced administration costs can lead to more money being spent on teaching and 
learning resources. At teacher and student level, ICT can reduce the chore of manually processing data, allowing more time for its interpretation and use. Teachers can use ICT tools to produce high-quality teaching materials which will stimulate more interest from students (NCET, 1997).

Despite the impact of ICT on society in general and the advantages of using it in teaching and learning, few schools and colleges are using ICT to its full potential. A major report from OFSTED (Office for Standards in Education, 1994) concluded that:

The breadth of ICT experience intended by the National Curriculum is yet to be achieved in the majority of schools. Much remains to ensure that pupils are not just 'exposed' to sophisticated ICT systems but achieve the levels of ICT capability required by the National Curriculum and understand the main implications of their use.

Research findings suggest that ICT is significantly under-used by student and beginning teachers. The problem is worldwide and many explanations are offered. Lack of resources or lack of access to resources in schools/ initial teacher training (ITT) institutions has been suggested by Veen (1993), Byard (1995), Wild (1996), Dearing (1997) and Taylor (1997). The lack of opportunity to use computers (Blackmore et al, 1992; Dunn \& Ridgway, 1991), predominance of other pressures during the early years of teaching (Wild, 1996), and the lack of ICT experience and training at pre-service level (Oliver, 1994; Wild, 1995) have also been implicated as factors leading to low student ICT uptake. Other suggestions include the lack of encouragement for students to use ICT by teachers in schools or teacher trainers (Dunn \& Ridgway, 1991; Downes, 1993; McDonald, 1993a; Collison \& Murray, 1994) and lack of confidence in the computing skills of student teachers and teacher trainers (Chen, 1997).

Conflicting reports have argued whether age is a significant factor in determining the extent of low student teacher ICT uptake (Woodrow, 1991; Blackmore et al, 1992; Liénard, 1995).

The effect of gender on computer use is also in dispute. Reports from Summers (1990) and McMahon \& Gardner (1995) suggest that male students are less anxious about ICT and make more frequent use of it. Several other studies have reported that female students are less confident or knowledgeable than males about using computers (Blackmore et al, 1992; Oliver, 1993; Marshall, 1997; Marshall \& Bannon, 1986). In contrast, there are also many reports which indicate that there are no significant differences between the attitudes of male and female students, for example: Koohang (1989), Kay (1989), Hunt \& Bohlin (1993), Marshall \& Bannon (1986) and Woodrow (1991).

The age phase for which students are being trained to teach may also be significant in that Blackmore et al (1992) and Oliver (1994) demonstrated respectively that primary-trained students were more anxious and used computers less than secondary-trained students. 
Finally, recent results from Summers \& Easdown (1996) indicate that the subject specialism of student teachers may influence the extent of ICT use. Students specialising in geography tended to use computers more in their teaching when compared with students who had chosen history as their main subject.

With the increasing emphasis on the requirement for teacher trainers and student teachers to become proficient in the use of educational technology, this article highlights the principal problems and obstacles which may have to be faced when developing and implementing institutional ICT policy.

\section{Methodology}

Eighty-nine teacher trainers from Queen's University, Stranmillis College and St Mary's College (all in Belfast) completed postal questionnaires.

Completed questionnaires were obtained from 119 PGCE students attending Queen's University during the academic year 1996-97 (all training to teach at secondary level).

The BEd questionnaires were collected during 'Professional Studies' classes (in which students are trained to teach the range of subject areas in the primary school) from students attending St Mary's College.

The first part of the questionnaire consisted of questions designed to collect data concerning access to, training in and use of computers, and the second part of the questionnaire consisted of a set of items designed to measure attitudes to computers.

A Likert scale (Likert, 1932) was adopted for measuring computer attitudes, and items were tested in a pilot study. The set of items was tested for reliability using an internal consistency method (Cronbach's Alpha coefficient, [Cronbach, 1990]), which yielded reliability coefficients of 0.827 and 0.805 for negative and positive items, respectively. Both of these values are higher than the 0.8 criterion which is regarded as internally reliable (Bryman \& Cramer, 1997).

Estimates of concurrent validity were measured using Pearson's product moment correlation coefficient. Highly significant positive correlations were observed between positive attitudes and the frequent use of computers.

\section{Results}

Use of ICT

A significantly higher proportion of lecturers than students claimed to use the following ICT facilities 'often' (see questionnaires, Appendix): word processing, email, Internet, discussion lists, computers for lesson preparation and computers in teaching (Figure 1). 
Within the student sample, PGCE students made much more extensive use of ICT than BEd students (Figure 2).

$70 \mathrm{~mm}$

Figure 1. Proportion of lecturers and students often using ICT facilities.

$70 \mathrm{~mm}$

Figure 2. Proportion of PGCE and BEd students often using ICT facilities.

Computer use in school during teaching practice was very low in both student groups. Only $24 \%$ of PGCE and $16 \%$ of BEd students often used computers on teaching practice. Indeed, $17 \%$ of PGCE and $34 \%$ of BEd students had never used a computer during teaching practice. 


\section{Access to Computers}

The lecturers in this sample had good computer access - seven out of 10 had use of a computer at home as well as at work. Most lecturers were able to use a machine in their office whenever they required, encountering none of the problems experienced by students attending open access centres. Only three out of 10 students had access to computers at both home and college.

On campus, students used departmental machines or attended open access centres. The PGCE students in this sample were attending Queen's University which is relatively well resourced in terms of computer access (over 500 machines are used in open access centres). However, access is dependent not only on the number of machines, but on their availability to students. Informal discussions with students indicated several problems when using computers at the open access centres, for instance: all machines being used; queuing to use a machine; unfamiliar software, and inconsistency of software between departments and open access centres; lack of technical support; insufficient opening hours; many machines 'too slow'; many machines 'out of order', and insufficient printing facilities.

The BEd students were sampled from St Mary's College, which is also well resourced in terms of the ratio of computers to students. However, one of the main problems at St Mary's is that most machines are unavailable outside normal working hours.

In an analysis of the effect of computer access on attitudes to computers, the mean response to almost all items reflecting attitudes towards liking, confidence and perceived level of training in computer use (word processing, email, Internet, discussion lists and teaching with computers) was significantly related to computer access. In addition, significant correlation $(p<0.05)$ was found between computer access and the extent of use of each of the facilities investigated (word processing, email, Internet, discussion lists and teaching with computers) by both lecturers and students (Murphy, 1997).

Students, particularly those who are novice computer users, require regular and adequate time to practise the new skills which they have been taught. Without this, many will become disaffected and even avoid using computers at all.

\section{Training}

The information on ICT training gathered for the present study gave an indication of whether or not the individual felt $\mathrm{s} /$ he was trained to use each of the following: word processing, email, the Internet, discussion lists and using computers for teaching. 
The results demonstrated that the lecturers felt they were not as well trained in ICT as the students (Figure 3), yet lecturers used computers more extensively than students. Further, the general response of lecturers to items suggesting that more ICT training would enhance their ability to teach with computers was more muted than that from the students (Murphy, 1997).

$50 \mathrm{~mm}$

Figure 3. ICT training among lecturers and students.

Approximately $90 \%$ of both PGCE and BEd students indicated that they had been trained to use word processing, with $84 \%$ PGCE students claiming to use word processing often. These figures are higher than those reported in previous studies. For example, the percentage of student teachers often using word processing has been quoted as: 1988: 16\% (Summers, 1990); 1989-90: 23\%; 1991-92: 38\%; 1992-93: 40\%; 1993-94: 47\% (Liénard, 1995); and 1994-95: 61\% (Murray \& Collison, 1995) (see Figure 4).

$50 \mathrm{~mm}$

Figure 4. Proportion of student teachers using word processing (adapted from several studies - see text for references). 
However, despite the high proportion of BEd students trained in word processing, less than $50 \%$ used it often. The following figures represent the percentage of students indicating they 'often use' each facility:

students $\%$ students \%

\begin{tabular}{lll}
\hline Word processing & 84 & 48 \\
The Internet & 19 & 10 \\
Computers for lesson preparation & 55 & 23 \\
Computers for teaching & 23 & 16 \\
\hline
\end{tabular}

Table I. Percentage of PGCE and BEd students who 'often' use various computer facilities.

Similar levels were recorded of use of email (6-7\%) and discussion lists (0-1\%) between PGCE and BEd students. The trend that emerged was that whilst the PGCE and BEd students did not markedly differ in the percentage who were trained, uptake was significantly greater by PGCE than by BEd students.

The data from PGCE and BEd students suggested little difference in ICT training between the two groups. However, the BEd students' attitudes towards training differed significantly from the PGCE group. The BEd students expressed a much stronger feeling that they would use computers more in class if they had more guidance. Furthermore, many of the respondents qualified their answer to the training questions (check-boxes) by adding comments such as "a little", "hardly any" or "not much". Clearly, there is a requirement for more specific information gathering regarding the type and extent of ICT training received by student teachers.

A follow-up enquiry to the institutions from which the students were sampled revealed differences in the expectations of tutors regarding the use of ICT by students in their coursework. The PGCE students were informed that, whilst not a requirement, it was highly desirable that all coursework submissions should be word processed. BEd students, on the other hand, were only required by certain subject departments to produce word-processed submissions. Informal observations (by the author) of Professional Studies coursework submitted by BEd students, for which there is currently no suggestion as to whether it should be word processed or not, revealed that $20-30 \%$ of students used word processing in coursework preparation during the 1996-97 academic year. This difference in the amount of encouragement by tutors to use ICT (albeit only word processing in this example) could account for the difference in ICT uptake between PGCE and $B E d$ students. The relative lack of encouragement for computer use by the BEd tutors in this study may underpin the students' strong desire for more ICT training. 


\section{ICT Confidence}

There was an ordering of confidence: lecturers > PGCE students $>$ BEd students in the non-specific use of computers. However, the ordering for confidence in using computers specifically in teaching ranked PGCE students slightly higher than lecturers (although the difference was not statistically significant). The BEd students expressed significantly less confidence in teaching with computers than both of the other groups. One explanation for the relatively low level of lecturer confidence in using computers in teaching could lie in the observation that most lecturers used their machines mainly for word processing and email. It is suggested that not many teacher trainers are as yet experimenting with the software which is or could be used in schools.

Within the lecturer sample, younger lecturers used computers more and were significantly more confident than those over 45 about using computers both generally and for teaching. No significant correlation was evident between lecturers over 45 and use of any computer facility. However, being under 45 was positively correlated $(p<0.05)$ with using email and with using computers in the preparation of lectures.

Within the student sample, the PGCE students were more confident than the BEd students in all aspects of computer use. Several reasons could be suggested to explain this difference in confidence: previous ICT experience, access to computers, encouragement to use ICT, age and gender.

The PGCE students may have had more computer experience during their first degree than the BEd students had during their prior school experience. The PGCE students also appeared to have more access than BEd students to computers. The PGCE students were more strongly encouraged than the BEd students to use computers in the preparation of their coursework. This undoubtedly would lead to increased familiarity and therefore increased confidence in computer use. The PGCE students were also a lot more confident than the BEd group about using computers during teaching practice. This may be due to the more frequent use of computers in coursework, leading to increased familiarity with computers and hence more confidence to work with computers in the classroom. It could also be suggested that there are more computers available for use in secondary than in primary schools, which would facilitate the more extensive integration of computers into teaching exhibited by the PGCE students in this study.

The difference in computer use in schools by PGCE and BEd students could be attributed to the BEd students' greater lack of confidence ( $24 \%$ of PGCE and $15 \%$ of BEd students often used computers on teaching practice; $17 \%$ of PGCE and $34 \%$ of BEd students had never used a computer during teaching practice). 
There was no significant effect of age on computer uptake by students in this study. However, a gender difference was evident. Women students in both PGCE and BEd groups were significantly less confident than male students about using computers in teaching (Murphy, 1997).

\section{Discussion}

One of the major implications of this study is that, despite their perception of being 'trained' to use ICT, over 75\% of the students (both PGCE and BEd) have never used a computer in class during their school experience.

Three major obstacles impeding the progress of effectively integrating ICT into teacher training can be identified: student access to computers, the ICT policy (or lack of) adopted by initial teacher training providers and the lack of encouragement for students to use ICT on teaching practice.

Effective delivery of the ICT Curriculum for Initial Teacher Training, implemented in September 1998 and outlined in the UK Teacher Training Agency's consultation document ITT National Curriculum for the Use of ICT in Subject Teaching (TTA, 1998), depends on these obstacles being recognised and addressed by ITT providers.

The strategy suggested below, which takes into account the major findings of this study, is intended to provide a generic approach towards enhancing student teacher uptake of ICT. Its success depends upon utilising effective school partnerships. Initial teacher training institutions should seek advice from school partners when formulating and implementing ICT policy.

\section{Enhancing Student ICT Uptake}

\section{ICT Access}

Institutions should work towards equipping all lecturers with an office computer which enables email and Intranet/Internet access. In addition to maximising computer provision for students in initial teacher training institutions, students could be encouraged to purchase a portable computer (with modem) prior to or at the start of their course. Clearly, there are cost and practical implications for the latter suggestion. Institutions could also start to build up a 'bank' of portable machines for student use (giving priority to novice users who require more practice).

One of the recommendations of the Dearing Report (1997) states that "We ... expect that by 2005-06 all students will be required to have access to their own portable computer".

At computer open access centres, the policy should include measures to provide longer opening hours, standardised software and hardware which are compatible with those used in schools, regularly upgraded machines, adequate printing facilities and trained support staff. 
Novice users could receive extra support in open access centres. The student log-on code could include an indication that the user is a beginner and support staff at the centre could access this information and be made aware of those students who may require more assistance. One problem with this approach is that some students may feel reluctant to admit a low level of ICT proficiency.

Government funding of new ICT resources for ITT providers is essential for effective delivery of the ICT Curriculum. As yet there is no funding for initial teacher training institutions equivalent to that earmarked for schools (related to the National Grid for Learning) to receive through Standard Funds (author's personal communication). The National Grid for Learning is a UK Government initiative to connect every school to the Internet and to provide a mosaic of inter-connecting on-line networks to support teaching, learning, training and administration in schools, colleges, universities, libraries, the workplace and homes.

\section{ICT Policy}

The ICT policy should emphasise the educational as opposed to the technical aspects of ICT, (for example: students in placement schools can access teaching resources and maintain synchronous and/ or asynchronous communication with peers and tutors). ICT training needs to be infused into all aspects of teacher training rather than presented in separate 'stand-alone' courses. Students should be familiarised with the major software packages being used in schools. They should critically evaluate such packages in the context of enhancing pupils' learning.

Teacher educators also need to be trained in the use of the major software packages which will be used by students in placement schools, (see McDonald, 1993b for details of an ICT staff development programme in which tutors were familiarised with and trained to use three such packages).

\section{Use of ICT during School Experience}

In addition to providing the broadest possible experience of the use of ICT in teaching and learning for students before they go into schools, tutors should support and assess a student's ICT competence during school placement. This information could be entered on a formative profile form and monitored throughout the course.

It is hoped that these basic guidelines will lay the foundations for effective ICT policy development and implementation. Individual initial teacher training institutions could adapt and add to them, depending on their existing structures and characteristics. Somekh et al (1997) provide some valuable insights into the effects of institutional structures and characteristics on the relative success of five initial teacher training 


\section{COLETTE MURPHY \& LILLIAN GREENWOOD}

institutions which were involved in the INTENT project (Initial Teacher Education and New Technology). They concluded that implementation:

... was most successful where it was sensitive to, but not hidebound by, the structure and culture of the organisation and the micropolitics of the institutional life. ... It was clear that, whatever the enthusiasms of the staff development tutor, involvement of a manager was often crucial to making progress. (p. 207)

A concerted effort on the part of initial teacher training institutions to prioritise ICT policy in their strategic planning will have far-reaching results. Effective delivery of the new ICT Curriculum for BEd and PGCE students should produce wellequipped teachers who will be able to realise the enormous potential of ICT in education.

\section{Correspondence}

Dr Colette Murphy, Graduate School of Education, Queen's University, 69-71 University Street, B elfast BT7 1HL, United Kingdom.

\section{References}

Blackmore, M., Stanley, N., Coles, D., Hodgkinson, K., Taylor, C. \& Vaughan, G. (1992) A preliminary view of students' information technology experience across UK initial teacher training institutions, Journal of Information Technology for Teacher Education, 1, pp. 241-254.

Bryman, A. \& Cramer, D. (1997) Quantitative Data Analysis. London: Routledge.

Byard, M. J. (1995) Information technology under school-based policies for initial teacher training, Journal of Computer Assisted Learning, 11, pp. 128-140.

Chen, Q. (1997) Training teacher educators: a case study of integrating information technology into teacher education, in D. Passey \& B. Samways (Eds) Information Technology: supporting change through teacher education. London: Chapman \& Hall.

Collison, J. \& Murray, D. (1994) What goes on in school-based IT?, Journal of Computer Assisted Learning, 11, pp. 99-109.

Cox, M. (1997) The Effects of Information Technology on Students' Motivation. Final Report. Coventry: National Council for Educational Technology (now the British Educational Communications and Technology agency [BECTa]).

Cronbach, L. J. (1990) Essentials of Psychological Testing. New York: Harper \& Row.

Dearing, R. (1997) Report of the National Committee of I nquiry into Higher Education. London: Her Majesty's Stationery Office (HMSO). Also available on-line at: http:/ / www.leeds.ac.uk/ educol/ ncihe

Downes, T. (1993) Student-teachers' experiences in using computers during teaching practice, Journal of Computer Assisted Learning, 9, pp. 17-33. 
Dunn, S. \& Ridgway, J. (1991) Computer use during primary school teaching practice: a survey, Journal of Computer Assisted Learning, 7, pp. 7-17.

Hunt, N. P. \& Bohlin, R. M. (1993) Teacher education students' attitudes toward using computers, Journal of Research on Computing in Education, 25, pp. 487-497.

Kay, R. H. (1989) Gender differences in computer attitudes, literacy, locus of control and commitment, J ournal of Research on Computing in Education, 21, pp. 307-316.

Koohang, A. A. (1989) A study of attitudes towards computers: anxiety, confidence, liking and perception of usefulness, Journal of Research on Computing in Education, 22, pp. 137-150.

Liénard, B. (1995) Pre-course information technology skills of teacher trainees: a longitudinal study, J ournal of Computer Assisted Learning, 11, pp. 110-120.

Likert, R. (1932) A Technique for the Measurement of Attitudes. New York: Colombia University Press.

Marshall, G. (1997) Time for change: critical issues in teacher education, in D. Passey $\&$ B. Samways (Eds) Information Technology: supporting change through teacher education. London: Chapman \& Hall.

Marshall, J. C. \& Bannon, S. H. (1986) Computer attitudes and computer knowledge of students and educators, Association for Education Data Systems J ournal, 18, pp. 270-286.

McDonald, S. (1993a) Information technology: building structures in initial teacher training to develop effective practitioners, Journal of Computer Assisted Learning, 9, pp. 141-148.

McDonald, S. (1993b) A model for staff development in information technology within initial teacher training institutions, J ournal of I nformation Technology for Teacher Education, 2, pp. 65-75.

McMahon, J. \& Gardner, J. (1995) Facilitating and inhibiting factors in student computer usage, in C. O'Hagan (Ed.) Empowering Teachers and Learners through Technology. Birmingham: Staff and Educational Development Association.

Murphy, C. (1997) Computer competence and attitudes of student teachers and teacher trainers. MSc (Education) thesis, Queen's University, Belfast.

Murray, D. \& Collison, J. (1995) Student information technology capability within a school-based primary initial teacher training course, Journal of Computer Assisted Learning, 11, pp. 170-181.

National Council for Educational Technology (1997) National Commission Briefing. Coventry: BECTa.

Office for Standards in Education (1994) Information Technology in Schools: the impact of the IT in Schools I nitiative, 1990-1993. London: HMSO.

Oliver, R. (1993) A comparison of students' information technology skills in 1985 and 1991, British J ournal of Educational Technology, 24, pp. $52-62$. 


\section{COLETTE MURPHY \& LILLIAN GREENWOOD}

Oliver, R. (1994) Factors influencing beginning teachers' uptake of computers, Journal of Technology and Teacher Education, 2, pp. 71-89.

Somekh, B., Whitty, G. \& Coveney, R. (1997) IT and the politics of institutional change, in B. Somekh \& N. Davis (Eds) Using Information Technology Effectively in Teaching and Learning: studies in pre-service and in-service teacher education. London: Routledge.

Summers, M. (1990) Starting teacher training - new PGCE students and courses, British Education and Research Journal, 16, pp. 79-87.

Summers, M. \& Easdown, G. (1996) Information technology in initial teacher training: preconceptions of history and geography interns, with reflections of mentors and tutors, Journal of Information Technology for Teacher Education, 5, pp. 155-172.

Taylor, C. (1997) Organising IT resources in educational institutional institutions, in B. Somekh \& N. Davis (Eds) Using Information Technology Effectively in Teaching and Learning: studies in pre-service and in-service teacher education. London: Routledge.

Teacher Training Agency (TTA) (1998) Initial Teacher Training National Curriculum for the Use of ICT in Subject Teaching. London: TTA.

Veen, W. (1993) The role of beliefs in the use of information technology: implications for teacher education, or teaching the right thing at the right time, Journal of Information Technology for Teacher Education, 2, pp. 139-153.

Wild, M. (1995) Pre-service teacher education programmes for IT: an effective education?, J ournal of Information Technology for Teacher Education, 4, pp. 7-20.

Wild, M. (1996) Technology refusal: rationalising the failure of student and beginning teachers to use computers, British Journal of Educational Technology, 27, pp. 134-143.

Woodrow, J. (1991) Locus of control and computer attitudes as determinants of the computer literacy of student teachers, Computers and Education, 16,

pp. 237-245. 
INTEGRATING ICT IN TEACHER EDUCATION

Appendix page 1 - no legend 
COLETTE MURPHY \& LILLIAN GREENWOOD

Appendix page 2 - no legend 
INTEGRATING ICT IN TEACHER EDUCATION

Appendix page 3 - no legend 